\title{
Inclusion of Yucca schidigera and zeolite in dog feed: influence on mineral excretion
}

\author{
[Inclusão de Yucca schidigera e zeólita em alimentos para cães: influência \\ sobre a excreção de minerais] \\ J.P.F. Santos ${ }^{1}$, F.M.O.B. Saad ${ }^{2}$, G.V.C. Maia $^{2}$, C.P. Pires ${ }^{2}$, J.S. Reis ${ }^{2}$, N.C. Roque ${ }^{2}$, \\ A.A. Aquino ${ }^{3}$, M.A. Brunetto ${ }^{1}$ \\ ${ }^{1}$ Faculdade de Medicina Veterinária e Zootecnia - Universidade de São Paulo - Pirassununga, SP \\ ${ }^{2}$ Universidade Federal de Lavras - Lavras, MG \\ ${ }^{3}$ Faculdade de Medicina Veterinária e Zootecnia - Universidade de São Paulo - São Paulo, SP
}

\begin{abstract}
This study aimed to evaluate the effects of adding Yucca schidigera and zeolite (Clinoptilolite) to feed (super premium and standard) for adult dogs on the apparent indigestibility coefficient of minerals. In the first assessment, $21 \mathrm{dogs}$ were used, with average weight of $12.5 \mathrm{~kg} \pm 1.46$ in seven treatments in two periods (super premium diet referred to as control and control with the addition of 125, 250,375ppm Yucca schidigera and $0.5 \%, 0.75 \%$ and $1.0 \%$ zeolite). The second assessment was conducted with standard feed, using 21 experimental plots distributed in three treatments (standard diet referred to as control and control with the addition of $375 \mathrm{ppm}$ of Yucca schidigera and $1.0 \%$ zeolite). The additives did not affect the acceptability of feed and fecal characteristics in both assessments $(\mathrm{P}>0.05)$. With the exception of calcium, no minerals were affected by the inclusion of additives $(P>0.05)$ in the experiment with super premium feed. In the assessment with standard feed, calcium as phosphorus and magnesium presented decreased excretion $(\mathrm{P}<0.05)$ with the inclusion of additives. It is possible to conclude that the inclusion of additives in the tested concentrations may interfere with the excretion of some minerals in the diet.
\end{abstract}

Keywords: adsorption, pets, clinoptilolite

\section{RESUMO}

Este trabalho teve como objetivo avaliar os efeitos da inclusão de Yucca schidigera e zeólita (Clinoptilolita) em alimentos (super premium e standard) para cães adultos sobre o coeficiente de indigestibilidade aparente de minerais. No primeiro ensaio, foram utilizados 21 cães, com peso médio de $12,5 \mathrm{~kg} \pm 1,46$, distribuídos em sete tratamentos em dois períodos (dieta super premium denominada controle e controle com adição de 125, 250, 375ppm de Yucca schidigera e 0,5\%, 0,75\% e 1,0\% de zeólita). $O$ segundo foi realizado com um alimento standard, utilizando-se 21 parcelas experimentais distribuídas em três tratamentos (dieta standard denominada controle e controle com adição de 375ppm de Yucca schidigera e 1,0\% de zeólita). Os aditivos não afetaram a aceitabilidade do alimento e as características fecais nos dois ensaios $(P>0,05)$. Com exceção do cálcio, nenhum mineral sofreu interferência da inclusão dos aditivos $(P>0,05)$ no experimento com alimento super premium. No ensaio com alimento standard, tanto cálcio quanto fósforo e magnésio apresentaram redução na excreção $(P<0,05)$ com a inclusão dos aditivos. Pôde-se concluir que a inclusão dos aditivos nas concentrações testadas pode interferir na excreção de alguns minerais da dieta.

Palavras-chave: adsorção, animais de companhia, clinoptilolita

Recebido em 1 de março de 2012

Aceito em 6 de março de 2013

E-mail: joao_paulo@zootecnista.com.br 


\section{INTRODUCTION}

There is a growing number of commercial feeds with the inclusion of additives with the potential to reduce fecal odor, a characteristic that directly impacts the interaction between pets and their owners. Among the fecal odor reducers, those that stand out are the Yucca schidigera extract (Lowe and Kershaw, 1997) and zeolite (Çabuk et al. 2004), which have distinct action mechanisms. The Yucca schidigera acts on the inhibition of urease, a bacterial enzyme related to the degradation of urea into ammonia in the environment, acting on the microbiota and binding with ammonia (Cheeke, 1999). As for zeolite, which is characterized by being an aluminosilicate, presents an imbalance of cargo in its structure and thus the affinity to absorb ammonia.

However, there are few studies on the relationship between these additives and nutrients in diets for dogs, especially minerals, and possible changes that might occur on the absorption of macro and micro minerals in feeds of different market segments. Market segmentation occurs in economical, standard, premium and super premium feeds. The standard feeds are characterized by variable formulation, with the inclusion of ingredients under their market availability and price, while the super premium feeds are products with high nutritional values that include special ingredients and fixed formulation. In the super premium segment there is a thorough unbalance and nutritional interaction control, which features higher digestibility coefficients compared to standard feed (Carciofi et al., 2006).

Thus, this study was conducted aiming to evalute the effect of the inclusion of Yucca schidigera and natural zeolite (Clinoptilolite) on the acceptability of feed (measured by dry matter intake), stool characteristics (average daily fecal output and percentage of water in the feces) and apparent indigestibility coefficient for calcium, phosphorus, magnesium, sodium, potassium, manganese, iron, copper and zinc, in adult dogs fed diets from the super premium and standard segments.

\section{MATERIAL AND METHODS}

The work was divided into two experimental assessments; the first was conducted using feed from the super premium segment and the second feed from the standard segment, according to the classification by the nutritional guide PIQ PET (Associação..., 2008). The experiments were performed at the CENAC (Center for Studies on Pet Nutrition), in the Department of Animal Husbandry, at the Universidade Federal de Lavras, approved by the Bioethics Committee (protocol 019/2009). The animals were housed, throughout the experimental period, in metabolic cages measuring $70 \times 85 \times 70 \mathrm{~cm}$ (height $\mathrm{x}$ width $\mathrm{x}$ depth). For the first assessment, 21 adult beagle dogs with average body weight of $12.5 \pm 1.46 \mathrm{~kg}$ and average age of four and a half years were used. The experiment was divided into two periods, and in each experimental period the animals were distributed in a completely randomized design, consisting of 7 treatments (control diet, control diet with addition of 125, 250 and 375ppm of Yucca schidigera and control diet with addition of $0.5 \%, 0.75 \%$ and $1.0 \%$ zeolite), with the animals being considered an experimental plot, totaling 42 experimental plots, and considering a period in the statistical model.

The control diet consisted of a wet feed added to dry feed. To supply of zeolite (clinoptilolite) and Yucca schidigera additives for the animals was dissolved in $10 \mathrm{ml}$ heated water and subsequently mixed with the wet feed (amount calculated to meet $10 \%$ of the energy requirement of the animals) and subsequently homogenized in the dry feed. The composition of the control, dry and wet diets are presented in Tab. 1. The amount of feed supplied to the animals was based on the formula for predicting maintenance energy requirement of $95 \mathrm{x}$ (body weight) ${ }^{0.75}$, according to the NRC (National..., 2006). 
Table 1. Bromatological analysis of the control, dry and wet diets employed in the study

\begin{tabular}{lcc}
\hline \multicolumn{1}{c}{ Nutrient (\%) } & Super Premium control diet & Standard control diet $^{2}$ \\
\hline Crude protein & 31.30 & 19.92 \\
Ethereal extract in acid hydrolyses & 19.20 & 7.74 \\
Fibrous matter & 3.16 & 2.18 \\
Mineral matter & 7.0 & 7.85 \\
Calcium & 1.55 & 1.89 \\
Phosphorus & 1.15 & 1.38 \\
\hline
\end{tabular}

${ }^{1}$ Composition of the dry diet: chicken; corn gluten meal; broken rice; ground whole corn grain; chicken by-products; flour; stabilized animal fat with tocopherols (vitamin E); corn bran; hydrolyzated chicken giblets; powdered egg; fish oil; L-lysine; potassium chloride; dicalcium phosphate; sodium chloride (standard salt); choline chloride; taurine; DL-methionine; ascorbic acid (vitamin C source); zinc sulfate; ferrous sulfate; vitamin premix (A; D3; B12); riboflavin; niacin; calcium pantothenate; manganese sulfate; biotin; thiamine mononitrate; folic acid; copper sulfate; pyridoxine hydrochloride; menadione bisulfite; sodium iodate calcium and sodium selenite. Composition of wet diet: water; chicken giblets; cattle giblets; pigs giblets; sodium chloride (common salt); carrageenan; vitamin and mineral premix.

${ }^{2}$ Composition: broken rice; ground whole corn grain; poultry meal; soybean meal; meat and bone meal; stabilized animal fat; brewer's dried yeast; hydrolyzed chicken and / or byproducts; corn gluten meal 60; wheat meal; dried potato; linseed seed; sodium chloride (standard salt); potassium chloride; colorants; dicalcium phosphate; vitamin premix and mineral premix.

${ }^{3}$ values expressed on dry matter.

In the second assessment, 21 adult beagle dogs with average body weight of $12.5 \pm 1.46 \mathrm{~kg}$, with an average age of four and a half years were used. The experimental design was completely randomized, consisting of three treatments (control diet referred to as standard, control diet with addition of $375 \mathrm{ppm}$ of Yucca schidigera and control diet with addition of $1.0 \%$ zeolite) with seven replicates per treatment. To calculate the feed supply it was necessary to adjust with an increase of 2.2 times in the calculation factor for the energy requirements of animals, compared to the first assessment and, therefore, the equation adopted was $200 \times \mathrm{BW}^{0} 75$. The composition of the feed used is presented in Tab. 1. Both in the adaptation and in the collection phases the administration of additives was performed using capsules (Vittara Farmácia de Manipulação, Lavras, MG), the control group received empty capsules as placebo.

In the assessments using super premium and standard feed, the adaptation and collection phases consisted of five days each, according to the recommendation from the AAFCO (Association..., 2009). Feces collection was performed twice daily, in the morning (8:00 am) and afternoon $(5: 00 \mathrm{pm})$ to minimize losses, as every collection was performed, the material was weighed and packed in plastic bags then taken to a freezer at $-20^{\circ} \mathrm{C}$. At the end of the experimental period, feces were homogenized (pool), reweighed and sent to an oven with forced ventilation at $65^{\circ} \mathrm{C}$ for 72 hours, weighed after reaching equilibrium with ambient temperature, ground using a hammer grinder and packed in plastic pots for subsequent chemical analysis.

The analyzes for the determination of calcium, phosphorus, sodium, potassium, magnesium, copper, zinc, iron and manganese were conducted at IMA (Institute of Agriculture of the state of Minas Gerais), located in Belo Horizonte, MG. The determinations were performed by atomic absorption spectrophotometer according to procedures recommended by Cantle (1982). Measurements of dry matter, crude protein, ash, fiber and gross energy for the characterization of feed were carried out according to Silva and Queiróz (2002).

The term digestibility may be used for minerals, nonetheless, it's not for the fact that minerals are digested, but because the mineral sources go through a digestibility processes. Since this work is focused on evaluating the excretion of minerals, the apparent indigestibility coefficient calculus adopted is presented Figure 1. 
Inclusion of Yucca schidigera...

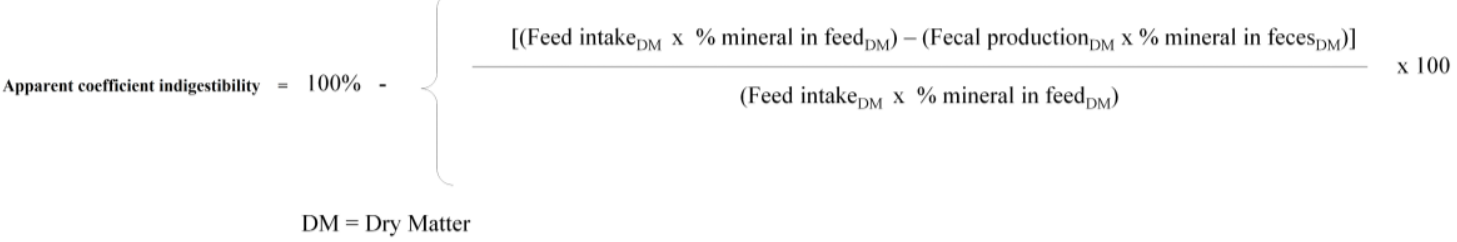

Figure 1. Methodology for calculating the coefficient for indigestibility of minerals.

The data was subjected to variance analysis and in order to do so the General Linear Models (GLM) statistical procedure and the Statistical Analysis System (Statistical..., 2004) statistical package were used. The Shapiro-Wilk test was performed to assess the normality of the residuals and maximum $\mathrm{F}$ test for variance homogeneity. Given the assumptions, the means were compared by the Student Newman-Keuls (SNK) test at the 5\% significance level.

\section{RESULTS AND DISCUSSION}

Data on average daily consumption (g / day) on dry matter basis, fecal output (g / day) and percentage of water in the feces obtained with super premium and standard feeds are arranged in Table 2.

It is possible to verify that there was no difference $(\mathrm{P}>0.05)$ in the average dry matter intake with the addition of the additives evaluated, in tested concentrations, in both experimental assessments. Thus, there was no influence on the acceptability of feed by the animals, confirming the results reported by Roque et al. (2011) and Maia et al. (2010) in palatability tests with additives for cats and dogs respectively, and Santos et al. (2011a) when assessing the acceptability of additives in cats. However, contrary to what was reported by Francis (2002), mentioning a reduction in dry matter intake in diets with the inclusion of Yucca schidigera for its astringent and irritating sensation and a possible reduction in gastrointestinal motility. Moreover, the results of this study are in line with those reported by Çabuk et al. (2004) who supplemented 120ppm of Yucca schidigera and $1.5 \%$ and $2.5 \%$ zeolite to the feed for broilers, and also found no differences in intake and Hauptli and Louvatto (2006), with the inclusion of 160ppm saponins for pigs.

Table 2. Average intake (g/day) of dry matter, production (g/day) of feces in natural matter and percentage $(\%)$ of water in the feces found in both experiments

\begin{tabular}{|c|c|c|c|c|c|c|c|}
\hline \multicolumn{4}{|c|}{ Super Premium diet } & \multicolumn{4}{|c|}{ Standard diet } \\
\hline Treatments & $\begin{array}{l}\text { Intake } \\
\text { (g/day) }\end{array}$ & $\begin{array}{c}\text { Fecal } \\
\text { production } \\
\text { (g/day) }\end{array}$ & $\begin{array}{l}\% \text { water } \\
\text { in feces }\end{array}$ & Treatments & $\begin{array}{l}\text { Intake } \\
\text { (g/day) }\end{array}$ & $\begin{array}{c}\text { Fecal } \\
\text { production } \\
(\mathrm{g} / \mathrm{d})\end{array}$ & $\begin{array}{l}\% \text { water } \\
\text { in feces }\end{array}$ \\
\hline Control & 139.88 & 40.05 & 60.35 & Control & 409.89 & 319.36 & 71.72 \\
\hline 125ppm YSE & 143.14 & 46.42 & 59.77 & & & & \\
\hline 250ppm YSE & 141.47 & 39.42 & 60.45 & 375ppm YSE & 436.50 & 312.08 & 72.06 \\
\hline 375ppm YSE & 139.09 & 37.87 & 59.61 & & & & \\
\hline $0.5 \% \mathrm{ZE}$ & 149.57 & 41.66 & 59.75 & & & & \\
\hline $0.75 \% \mathrm{ZE}$ & 141.43 & 38.07 & 59.73 & $1.0 \% \mathrm{ZE}$ & 423.03 & 301.91 & 71.33 \\
\hline $1.0 \% \mathrm{ZE}$ & 140.73 & 38.42 & 58.68 & & & & \\
\hline $\mathrm{CV}(\%)$ & 9.15 & 8.28 & 2.52 & $\mathrm{CV}(\%)$ & 13.60 & 21.40 & 3.04 \\
\hline $\mathrm{P}^{*}$ & 0.8845 & 0.1527 & 0.5401 & $\mathrm{P}$ & 0.7289 & 0.8966 & 0.8451 \\
\hline
\end{tabular}

YSE: Yucca schidigera; ZE: Zeolite; *Significance $\mathrm{P}<0.05$

Regarding the zeolite, its inclusion could reduce the voluntary intake because it is a mineral of volcanic origin, resembling clay. However,
Shurson et al. (1984) also found no difference in the intake of pigs receiving $0.5 \%$ clinoptilolite. There were no significant differences $(\mathrm{P}>0.05)$ on the production of feces (g/day) and the 
percentage of water in the feces, with the inclusion of additives in super premium and standard feed, similar to Santos et al. (2011a) when working with cats, and Lowe and Kershaw (1997), when supplementing 250ppm Yucca schidigera for dogs, who found no effect of the additive on the frequency of defecation, fecal output and format, as well as the retention time of fecal volume. Moreover, Hauptili and Lovatto (2006) reported an improvement in the fecal score of pigs. The latter authors worked with fecal score rather than percentage of water in the feces, the fecal score, however, presents a far greater degree of subjectivity.

For minerals, the term digestibility is used today not because the minerals are digested, but the sources of minerals go through the digestion process. Thus, in Tab. 3 we show the coefficient of apparent indigestibility of calcium, phosphorus, magnesium, sodium, potassium, iron, manganese, copper and zinc in the assay with super premium feed.
It is possible to verify that phosphorus, magnesium, sodium, potassium, iron, manganese, copper and zinc were not affected $(\mathrm{P}>0.05)$ in their excretion with the inclusion of additives, corroborating Santos et al. (2011a), but the inclusion of Yucca schidigera at concentrations of 250 and $375 \mathrm{ppm}$ increased calcium excretion in comparison to the control group (12.36\% and $13.12 \%$, respectively), in the same way as the treatments with zeolite increased the excretion of calcium at concentrations of $0.5 \%$ and $1.0 \%(13.8 \%$ and $23.17 \%$, respectively). As for the treatments with $125 \mathrm{ppm}$ of Yucca schidigera and $0.75 \%$ zeolite, they did not differ from the control group, but were below the maximum level $(1.0 \%)$ of zeolite $(17.66 \%$ and $14.17 \%$, respectively). Thus, both the Yucca schidigera and zeolite had a negative effect on apparent absorption of the mineral. However, the highest concentration of zeolite $(1.0 \%)$ caused a greater impact.

Table 3. Apparent coefficient indigestibility of calcium (Ca), phosphorus (P), magnesium (Mg), sodium $(\mathrm{Na})$, potassium $(\mathrm{K})$, iron $(\mathrm{Fe})$, manganese $(\mathrm{Mn})$, copper $(\mathrm{Cu})$ and zinc $(\mathrm{Zn})$ in the experiment with super premium feed

\begin{tabular}{cccccccccc}
\hline Treatment & $\mathrm{Ca}$ & $\mathrm{P}$ & $\mathrm{Mg}$ & $\mathrm{Na}$ & $\mathrm{K}$ & $\mathrm{Fe}$ & $\mathrm{Mn}$ & $\mathrm{Cu}$ & $\mathrm{Zn}$ \\
\hline Control & $48.41 \mathrm{c}$ & 40.05 & 15.50 & 6.82 & 2.54 & 89.63 & 63.84 & 51.96 & 84.92 \\
125ppm YSE & $53.92 \mathrm{bc}$ & 40.94 & 12.75 & 5.50 & 2.52 & 74.06 & 55.11 & 48.60 & 79.67 \\
250ppm YSE & $60.77 \mathrm{ab}$ & 43.72 & 16.86 & 5.72 & 2.20 & 79.48 & 62.22 & 52.24 & 85.02 \\
375ppm YSE & $61.53 \mathrm{ab}$ & 47.45 & 15.98 & 5.89 & 2.91 & 84.60 & 64.89 & 51.32 & 87.80 \\
$0.5 \% \mathrm{ZE}$ & $62.21 \mathrm{ab}$ & 37.86 & 15.44 & 4.86 & 2.25 & 71.93 & 62.02 & 50.60 & 83.27 \\
$0.75 \% \mathrm{ZE}$ & $56.88 \mathrm{bc}$ & 42.67 & 14.20 & 6.34 & 3.42 & 66.71 & 54.94 & 48.46 & 81.37 \\
$1.0 \% \mathrm{ZE}$ & $71.58^{\mathrm{a}}$ & 49.91 & 15.10 & 6.00 & 3.16 & 65.66 & 56.39 & 50.22 & 78.38 \\
\hline $\mathrm{CV}(\%)$ & 15.60 & 16.97 & 20.97 & 27.15 & 21.12 & 21.61 & 12.91 & 10.36 & 10.19 \\
\hline $\mathrm{P}^{*}$ & 0.0002 & 0.0972 & 0.4292 & 0.6226 & 0.2618 & 0.1979 & 0.0765 & 0.8502 & 0.4473 \\
\hline
\end{tabular}

YSE: Yucca schidigera; ZE: Zeolite

*Significance $\mathrm{P}<0.05$

For Sonnenholzer (2004), the exponential model is best to explain the behavior of ammonia aluminiossilicate when it is kept constant because the adsorbents are most efficient when there is a high concentration of solute over the quantity of adsorbents. The author presents a table in which the adsorption of ammonia by the zeolite was $1.53,0.91$ and $0.70 \mathrm{mg} / \mathrm{g}$, with the addition of $1.0,10.0$ and $15.0 \mathrm{~g}$ zeolite, respectively. The data in this study disagrees with Shurson et al. (1984) working with pigs to evaluate the effect of increasing levels of hydrated sodium zeolite $(0 \%, 1 \%, 2 \%$ and $3 \%)$ and clinoptilolite $(0 \%, 2.5 \%, 5.0 \%$ and $7.5 \%)$ and mentioned a linear decrease in calcium retention only with hydrated sodium zeolite, without clinoptilolite action on the mineral. The authors mention that the hydrated sodium zeolite is less stable than the clinoptilolite at low $\mathrm{pH}$, such as in the stomach, and that the aluminum in its structure could interfere negatively on calcium absorption. Likewise, Barros et al. (2003), working with hydrated sodium zeolite for chickens, found an increase in the excretion of calcium and phosphorus with the addition of the additive.

Regarding the phosphorus data, the findings in this study were as expected, since natural zeolite such as clinoptilolite has a low affinity for 
anions, given its unbalanced loads as mentioned by Paiva et al. (2004), mentioning that the negative charges of the tetrahedral $\mathrm{AlO}_{4}$ are compensated by alkali or alkaline earthy cations, which can be replaced by other cations during the process of cation exchange.

Regarding the Yucca schidigera, several theories can be raised about its action in increasing the excretion of calcium, either through their action on intestinal microbiota, on reducing the digestibility of lipids and on binding with minerals or membrane transporters.

Cheeke (1999) mentions that Yucca schidigera acts on protozoa and gram-positive bacteria, similar to the action of ionophores, changing the surface tension of the extracellular matrix, causing disruption and cell lysis. Among the gram-positive strains Lactobacillus spp. stand out as homofermentatives microorganisms that have, as the only product of the fermentation, lactic acid, a product which has high capacity to reduce the $\mathrm{pH}$ of the intestinal tract, and this is one condition to facilitate calcium absorption due to its ionization.

Regarding the reduction in the coefficient of ether extract digestibility and increased calcium excretion, Calvert et al. (1981) found increased excretion of bile salts by including saponins in the diet of humans. Bile salts are directly involved in the digestion of lipids. Thus, the negative effect of saponins on bile salts reflects the reduction in micelle formation and emulsification of dietary lipids and, consequently, in their absorption, corroborating the findings of Santos et al. (2011b) who also found a reduction in the digestibility of dietary acid hydrolyzed fat in diets for dogs with the inclusion of Yucca schidigera. Jenkins and Atwal (1994) evaluated diets with $0.9 \%$ saponins for broilers and found a reduction in the digestibility of lipids as well as interference with absorption of fat-soluble vitamins. Thus, an increase in the excretion of lipids could reflect a reduction in the digestibility of calcium, by the phenomenon known as saponification by calcium (McDowell, 1992).

As for sodium and potassium, the findings of this study are similar to the findings by Shurson et al. (1984) who also found no reduction in the absorption of sodium in clinoptilolite supplementation. However, they disagree with Lima et al. (2008), who mentions a preference of adsorption of clinoptilolite by $\mathrm{Cs}^{+}>\mathrm{K}^{+}>\mathrm{NH}_{4}^{+}>\mathrm{Sr}^{2+}>\mathrm{Na}^{+}>\mathrm{Ca}^{2+}>\mathrm{Fe}^{3+}>\mathrm{Al}^{3+}>\mathrm{Mg}^{2+}$, with the $\mathrm{K}^{+}$ion as the main competitor of the $\mathrm{NH}_{4}{ }^{+}$ion for the exchange sites, thus the ammonia prevented the adsorption of potassium by competition for exchange sites. This fact takes greater importance when evaluating the work of Roque et al. (2011) and Maia et al. (2010), when employing the same concentrations of zeolite studied. These authors found a reduction in odor from the feces of dogs and cats, possibly by the action of zeolite on ammonia.

Regarding micro-minerals, data from this study are similar to those obtained by Shurson et al. (1984) and Omoruyi et al. (2006), however, they disagree with West et al. (1978), who found complexes formed between the root saponins of alfalfa and zinc and iron, in an in vitro study. Another factor to be considered is the competition of minerals for exchange sites of the zeolite. Motsi et al. (2009) found a reduction in the adsorption of $\mathrm{Cu}^{2+}, \mathrm{Zn}^{2+}$ e $\mathrm{Mn}^{2+}$, evaluated in mixed solutions, when compared to simple solutions. Tab. 4, presents the apparent indigestibility coefficients of calcium, phosphorus, magnesium, sodium and potassium in the experiment with standard feed.

Table 4. Apparent coefficient indigestibility of calcium (Ca), phosphorus (P), magnesium (Mg), sodium $(\mathrm{Na})$, potassium $(\mathrm{K})$, iron $(\mathrm{Fe})$, manganese $(\mathrm{Mn})$, copper $(\mathrm{Cu})$ and zinc $(\mathrm{Zn})$ in the experiment with standard feed

\begin{tabular}{cccccc}
\hline Treatments & $\mathrm{Ca}$ & $\mathrm{P}$ & $\mathrm{Mg}$ & $\mathrm{Na}$ & $\mathrm{K}$ \\
\hline Control & $78.06 \mathrm{a}$ & $69.94 \mathrm{a}$ & $80.63 \mathrm{a}$ & 23.45 & 13.12 \\
375ppm YSE & $65.01 \mathrm{~b}$ & $60.09 \mathrm{~b}$ & $52.08 \mathrm{c}$ & 20.83 & 13.37 \\
$1.0 \% \mathrm{ZE}$ & $70.95 \mathrm{ab}$ & $60.36 \mathrm{~b}$ & $70.41 \mathrm{~b}$ & 22.14 & 14.64 \\
$\mathrm{CV}(\%)$ & 12.54 & 12.41 & 19.81 & 25.73 & 28.27 \\
\hline $\mathrm{P}^{*}$ & 0.0219 & 0.0219 & $<0.0001$ & 0.7320 & 0.7584 \\
\hline
\end{tabular}

YSE: Yucca schidigera; ZE: Zeolite

*Significance $\mathrm{P}<0.05$ 
There were significant differences $(\mathrm{P}<0.05)$ on the apparent excretion of calcium, phosphorus and magnesium, when using the inclusion of additives in standard feed. When comparing the assessments, it was observed that, in the super premium feed, the apparent indigestibility coefficients of calcium, phosphorus and magnesium were lower than in standard feed, this finding could be explained by the source used in different feeds, and by a negative relationship between increased dietary minerals and their absorption, corroborating the findings by Hazenwinkel et al. (1991) who mention actual absorption of calcium between 70\%-91\%; $23 \%-43 \%$; and $45 \%-65 \%$ for feed with low, normal and high percentage of calcium $(0.55 \%$, $3.3 \%$, and $1.1 \%$, respectively).

Regarding the apparent indigestibility coefficient of calcium, it can be seen that there was a reduction $(\mathrm{P}<0.05)$ in calcium excretion for the treatment with $375 \mathrm{ppm}$ of Yucca schidigera. One possible explanation for the finding in this study regarding the calcium element is that interaction may have occurred between the percentage of nitrogen-free extractives in the diet $(62.3 \%$ on a dry matter basis) and microbial population. As previously mentioned, the Yucca schidigera presented a negative effect on the membrane of microorganisms, such as Lactobacillus spp., which produces lactic acid and consequently reduces the $\mathrm{pH}$ of the environment. However, Sen et al. (1998) reported that supplementation with saponins at low concentrations may lead to increased membrane translocation of nutrients by microorganisms and stimulate its growth. Thus, the supplementation of saponins in diets with high percentages of nitrogen-free extractives could increase the nutritional intake of microorganisms and its efficiency related to the production of secondary metabolites, such as lactic acid, lowering the $\mathrm{pH}$, increasing ionization of the mineral and, in response, an increasing absorption. This fact takes on greater significance when comparing the data from this assessment with the previous assessment, with super premium feed, which used the same level of inclusion of the additive and decreased the apparent digestibility of calcium. However, the super premium diet had $39.54 \%$ nitrogen-free extractives on a dry matter basis, while the standard presented $62.31 \%$.

Regarding phosphorus, the difference $(\mathrm{P}<0.05)$ found in the control treatment for additives may be related to the physiological mechanism to maintain the Ca:P ratio. According Schoulten et al. (2002), working with different calcium levels for broilers and percentage of phosphorus fixed, the authors suggest that the increase in the level of calcium in the diet may result in decreased absorption of calcium and phosphorus.

As for magnesium, unlike the finding in the trial with super premium feed, a difference was found $(\mathrm{P}<0.05)$ between treatments. The inclusion of $375 \mathrm{ppm}$ Yucca schidigera led to increased mineral absorption, with apparent indigestibility coefficient of $52.08 \%$. The explanation for this fact might be the same used for calcium, reducing the $\mathrm{pH}$ of the intestinal lumen, caused by an interaction between the saponins and the level of nitrogen-free extractives in the diet. The inclusion of $1.0 \%$ zeolite decreased the indigestibility of magnesium (70.41\%) compared to the control treatment $(80.63 \%)$. McDowell (1992) mentions that complexes formed between magnesium and phosphorus may occur which leads to reduced absorption from magnesium. Thus, the increase in the excretion of phosphorus may have led to the formation of complexes with magnesium, reflected in reduced absorption.

\section{CONCLUSION}

The inclusion of Yucca schidigera and zeolite in both standard and super premium feed did not interfere negatively on dry matter intake and fecal characteristics. However, it could be verified that both additives lead to changes in calcium excretion. However, there are differences in the behavior of additives on mineral excretion in relation to the market segment in which the food is placed. Thus, in dog feed, the inclusion of additives must be accompanied by extensive knowledge of the digestibility and bioavailability of mineral sources used in order to prevent nutritional imbalance. 


\section{REFERENCES}

ASSOCIAÇÃO Nacional dos Fabricantes de Alimentos pet Manual do programa integrado de qualidade pet Ed. dos Editores: São Paulo, 2.ed., 238p., 2008.

ASSOCIATION of American Feed Control Officials - AAFCO. Official Publications 2004. Association of American Feed Control Officials, 2004.

BARROS, S.E.C.; CURVELLO, F.A.; MACHADO JÚNIOR, H.F.; GOMES, A.V.C. Efeitos "in vitro" da zeólita NaY sobre fontes de cálcio e fósforo em rações para frangos de corte. Rev. Univ. Rural: Série Ciências da Vida, v.22, p.89-95, 2003.

ÇABUK, M.; ALÇIÇEK, A.; BOZKURT, M.; AKKAN, S. Effect of Yucca schidigera and natural zeolite on broiler performance. Inter. $J$. Poultry Sci., v.10, p.651-654, 2004.

CALVERT, G.D.; BLIGHT, L.; ILLMAN, R.J. et al. A trial of the effects of soyabean flour and soyabean saponins on plasma lipids, faecal bile acid and neutral sterols in hypercholesterolemic men. Brit. J. Nutrit., v.45, p.277-281, 1981.

CANTLE, J.E. Atomic absorption spectrometry. New York: Elsevier Scientific, 1982. v.5, 448p.

CARCIOFI A.C.; VASCONCELOS R.S.; BORGES, A.C. et al. Composição nutricional e avaliação de rótulos de rações para cães comercializadas em Jaboticabal-SP. Arq. Bras. Med. Vet. Zootec., v.58, p.421-426, 2006.

CHEEKE, P.R. Actual and potential applications of Yucca schidigera and Quillaja saponaria saponins in human and animal nutrition. J. Anim. Sci., v.77, p.1-10, 1999.

FRANCIS, G.; KEREM, Z.; MAKKAR, H.P.S.; BECKER, K. The biological action of saponins in animal systems: a review. British J. Nutrition, v.88, p.587-605, 2002.

HAUPTLI, L.; LOVVATO, P.A. Alimentação de porcas gestantes e lactantes com dietas contendo saponinas. Cienc. Rural, v.36, p.610-616, 2006.

HAZEWINKEL, H.A.W.; VAN DEN BROM, W.; TH. VAN`T KLOOSTER, A. et al. Calcium Metabolism in Great Dane Dogs Fed Diets with Various Calcium and Phosphorus Levels. J. Nutrition, v.121, p.99-106, 1991.
JENKIS, K.J.; ATWAL, A.S. Effects of dietary saponins on fecal bile acids and neutral sterols, and availability of vitamins $A$ and $E$ in the chick. The J. Nutrition Biochemistry, v.5, p.134-147, 1994.

LIMA, R.M.G.; WILDHAGEN, G.R.S.; CUNHA, J.W.S.D. Remoção de íon amônia de águas produzidas na exploração de petróleo em áreas offshore por adsorção em clinoptilolita. Química Nova, v.31, p.1237-1242, 2008.

LOWE, J.A.; KERSHAW, A.S. The ameliorating effect of Yucca schidigera extract on canine and feline faecal aroma. Res. Vet. Sci., v.63, p.61-66, 1997.

MAIA, G.V.C.; SAAD, F.M.O.B.; ROQUE, N.C. et al. Zeólitas e Yucca schidigera em rações para cães: palatabilidade, digestibilidade e redução de odores fecais. Rev. Bras. Zootec., v.19, p.2242-2246, 2010.

McDOWELL, L.R. Minerals in animal and human nutrition. London: Academic, 1992. $524 \mathrm{p}$.

MOTSI, T.; ROWSON, N.A.; SIMMONS, M.J.H. Adsorption of heavy metals from acid mine drainage by natural zeolite. Inter. $J$. Mineral Processing, v.32, p.42-48, 2009.

NATIONAL Research Council-NRC. Nutrient requirements of dogs and cats. Washington, D.C: National Academy of Science, National Academy Press, 2006. 398 p.

OMORUYI, F.O.; McANUFF-HARDING, M.; ASEMOTA, H.N. Intestinal lipids ans minerals in streptozotocin-induced diabetic rats fed bitter yam (Dioscorea polygonoides) sapogenin extract. Pakistan J. Pharmaceut. Sci., v.19, p.269-275, 2006.

PAIVA, P.R.P.; MONTE, M.B.M; DUARTE, A.C.P. et al. Aplicação de zeolita natural como fertilizante de liberação lenta. IN: XX ENTMME - Encontro Nacional de Tratamento de Minérios e Metalúrgica Extrativa, 2004.

ROQUE, N.C.; SAAD, F.M.O.B.; SANTOS, J.P.F. et al. Increasing levels of zeolite and Yucca schidigera in diets for adult cats. Rev. Bras. Zootec., v.40, p.2471-2475, 2011. 
SANTOS, J.P.F.; SAAD, F.M.O.B.; ROQUE, N.C. et al. Yucca schidigera e zeólita em alimento para gatos e seus efeitos na excreção de minerais. Arq. Bras. Med. Vet. Zootec., v.63, p.687-693, 2011a.

SANTOS, J.P.F.; SAAD, F.M.O.B.; AQUINO, A.A. et al. Inclusão de Yucca schidigera e zeólita (Clinoptilolita) em alimento comercial para cães adultos e seus efeitos sobre a digestibilidade de nutrientes. In: SIMPÓSIO DE PÓS-GRADUAÇÃO E PESQUISA EM NUTRIÇÃO E PRODUÇÃO ANIMAL, 5., 2011, Pirassununga. Anais... Editora 5D, p. 1-5 (Resumo), 2011b.

SEN, S.; MAKKAR, H.P.S.; MUETZEL, M.; BECKER, K. Effect of Quillaja saponaria saponins and Yucca schidigera plant extract on growth Escherichia coli. Letters in Appl. Microb., v.27, p.35-39, 1998.

SCHOULTEN, N.A.; TEXEIRA, A.S.; BERTECHINI, A.G. et al. Efeito nos níveis de cálcio sobre a absorção de minerais em dietas inicias para frangos de corte suplementadas com fitase. Cienc. Agrotecnol., v.26, p.1313-1321, 2002.
SHURSON, G.C.; KU, P.K.; MILLER, E.R.; YOKOYAMA, M.T. Effects of zeolite a or clinoptilolite in diets of growing swine. J. Anim. Sci., v.59, p.1536-1545, 1984.

SILVA, D.J.; QUEIROZ, A.C. Análises de alimentos (métodos químicos e biológicos). 3.ed. Viçosa, MG: Editora UFV, 2002. 235p.

SONNENHOLZER, S. Ensayo de remoción de amonio por mineral zeolita: efecto del radio del soluto (amonio) com respecto al absorbente (zeolita). Cenaim Informa - Boletim Informativo, v.110, p. 1-1, 2004.

STATISTICAL analysis system. SAS INSTITUTE. SAS User's guide: statistics. 5.ed., SAS Inst., Cary: NC, 1985.

WEST, L.G.; GREGER, J.L.; WHITE, A.; NONNAMAKER, B.J. In vitro studies on saponin-mineral complexation. J. Food Sci., v.43, p.1342-1343, 1978. 